\title{
Keberlanjutan Sistem Penyediaan Air Minum Berbasis Masyarakat Desa Piji dan Desa Gintungan Di Kabupaten Purworejo
}

\author{
*Andito Sidiq Swastomo, Doddy Aditya Iskandar \\ Departemen Teknik Arsitektur dan Perencanaan, Magister Perencanaan Wilayah dan Kota, Universitas Gadjah Mada, Yogyakarta \\ *asswastomo@gmail.com, doddy@ugm.ac.id
}

\section{INFO ARTIKEL}

Riwayat Artikel:

Diterima:08-01-2020

Disetujui:30-04-2020

\section{Kata Kunci:}

Penyediaan air minum, Keberlanjutan,

Modal manusia,

Modal sosial

\begin{abstract}
ABSTRAK
Abstrak: Pencapaian target SDG's penyediaan akses air minum bagi seluruh masyarakat membutuhkan usaha dan kerja keras dari pemerintah. Beberapa program pembangunan infrastruktur air minum telah diluncurkan oleh pemerintah guna memenuhi kebutuhan layanan dasar bagi masyarakat khususnya pada wilayah perdesaan. Namun dalam perkembangan pasa konstruksi, SPAM Desa terbangun mengalami perkembangan yang berbeda-beda. Penelitian ini bertujuan untuk mengetahui keberlanjutan sistem penyediaan air minum pedesaan berbasis masyarakat dan faktor-faktor yang mempengaruhi keberlanjutan sistem tersebut. Penelitian ini menggunakan pendekatan kualitatif dengan metode studi kasus. Desain penelitian yang digunakan adalah multikasus olistik dengan dua desa penelitian yaitu Desa Piji dan Desa Gintungan. Hasil penelitian menunjukkan bahwa sistem penyediaan air minum pedesaan dengan pendekatan berbasis masyarakat mempunyai keberlanjutan yang berbeda-beda. Desa dengan keberlanjutan pada aspek sosial, keuangan, lingkungan dan kelembagaan mempunyai tingkat keberlanjutan yang sangat baik sedangkan desa dengan keberlanjutan hanya pada salah satu aspek saja mempunyai tingkat keberlanjutan yang rendah. Hal ini terlihat pada sistem penyediaan air minum di Desa Piji yang mengalami keberlanjutan sebaliknya pada Desa Gintungan tidak terjadi keberlanjutan. Keberlanjutan SPAM Desa sangat dipengaruhi oleh modal sosial dan modal manusia yang dimiliki. Pada kedua desa penelitian, faktor modal sosial yang mempengaruhi berupa jaringan hubungan sosial yang kuat, kepercayaan, dan norma aturan, sedangkan faktor modal manusia yang berpengaruh berupa motivasi, komitmen, efektivitas tim kerja dan kepemimpinan.
\end{abstract}

\begin{abstract}
Achieving the SDG's target of providing access to water for all communities requires effort and hard work from the government. Several water supply infrastructure development programs have been launched by the government to meet basic service needs for the community, especially in rural areas. However, in the development phase of construction, the SPAM Desa was developed experiencing different developments. This study aims to determine the sustainability of the community-based rural water supply system and the factors that influence the sustainability of the system. This research uses a qualitative approach with a case study method. The research design used was an olistic multicase with two research villages namely Piji Village and Gintungan Village. The results showed that the rural water supply system with a community-based approach has a different sustainability. Villages with sustainability in social, financial, environmental and institutional aspects have a very good level of sustainability while villages with sustainability in only one aspect have a low level of sustainability. This can be seen in the water supply system in Piji Village which experiences sustainability whereas in Gintungan Village there is no sustainability. Sustainability of SPAM Desa is strongly influenced by social capital and human capital they have. In the two research villages, social capital influencing factors are in the form of a strong social relations network, trust and rule norms, while influential human capital factors are motivation, commitment, work team effectiveness and leadership.
\end{abstract}

\section{A. LATAR BELAKANG}

Pemenuhan kebutuhan air mulai menjadi prioritas dan diadopsi oleh negara-negara anggota PBB semenjak adanya deklarasi Millennium Development Goals (MDGs) pada September 2009. Mulai Tahun 2015 Agenda ini digantikan oleh Sustainable Development Goals (SDG's), salah satu tujuan aksi ini adalah untuk menjamin akses atas air dan sanitasi untuk semua.
Pemerintah Indonesia sebagai negara yang ikut dalam agenda tersebut menempatkan tujuan itu sebagai salah satu prioritas penyediaan layanan dasar dalam pembangunan nasional. Pemerintah menargetkan dalam RPJMN 2015--2019 bahwa pada akhir tahun 2019 cakupan akses air minum layak secara menyeluruh di Indonesia mencapai 100\% (Universal Access).

Pencapaian target penyediaan akses bagi seluruh masyarakat membutuhkan usaha dan kerja keras dari 
pemerintah dalam melakukan pembangunan layanan air. Beberapa pengalaman pelaksanaan pembangunan air minum di Indonesia sebelumnya menunjukkan bahwa pembangunan pelayanan air minum dan penyehatan lingkungan yang melibatkan masyarakat, memiliki efektivitas dan keberlanjutan pelayanan yang lebih baik, selain itu pengelolaan prasarana dan sarana yang melibatkan seluruh lapisan masyarakat pengguna dalam pengambilan keputusan dan kelembagaan, menghasilkan partisipasi masyarakat yang lebih besar pada pelaksanaan operasi dan pemeliharaan [1]. Dalam konteks air minum dan penyehatan lingkungan, keberlanjutan dapat diartikan sebagai upaya dan kegiatan penyediaan air minum dan penyehatan lingkungan yang dilakukan untuk dapat memberikan manfaat dan pelayanan kepada masyarakat pengguna secara terus menerus [1]. sedangkan Schuringa dalam Kamulyan, dkk (2017)[3] mendefinisikan bahwa sistem penyediaan air dikatakan berkelanjutan ketika : sistem itu berfungsi dan digunakan, sistem tersebut mampu memberikan tingkat manfaat yang sesuai (kualitas, kuantitas, keteraturan, kesediaan, efisiensi, kesetaraan, keandalan dan kesehatan), berjalan dalam jangka waktu yang lama tanpa berdampak buruk pada lingkungan, semua pembiayaan operasional dan pemeliharaan terpenuhi, terdapat lembaga yang mengelola, dan mendapat dukungan yang layak dari pihak luar. Sementara itu menurut Mukherje, N \& van Wijk dalam Trijunianto, 2016)[8] pada keberlanjutan untuk pembangunan air minum dan sanitasi terdapat 5 (lima) aspek, yaitu : teknis, sosial, keuangan, lingkungan, dan kelembagaan. Kelima aspek tersebut merupakan aspek yang saling mempengaruhi dan ketergantungan.

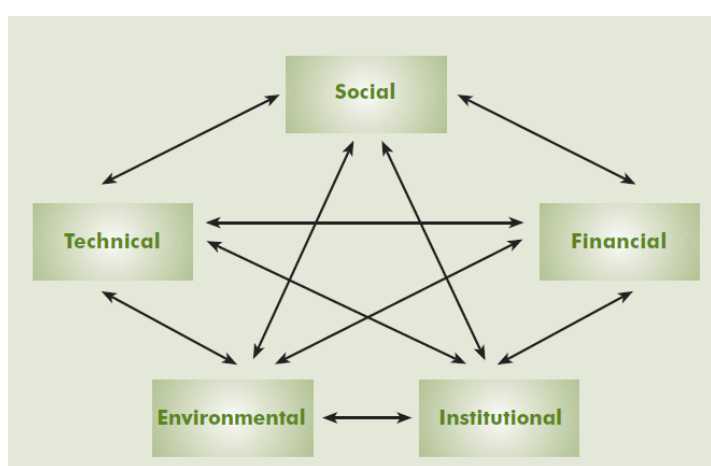

Gambar 1.Kunci Aspek Keberlanjutan Sarana Air Minum

Salah satu program pembangunan infrastruktur air minum yang melibatkan masyarakat guna memenuhi kebutuhan layanan dasar bagi masyarakat yang tidak terlayani oleh sistem publik khususnya pada wilayah perdesaan adalah Program Penyediaan Air Minum Dan Sanitasi Berbasis Masyarakat (Pamsimas). Sebagai program dengan pendekatan berbasis masyarakat maka karakteristik dan kondisi modal manusia dan modal sosial suatu wilayah menjadi faktor penting dalam keberhasilan program. Menurut Rustiadi dkk (2009) kapasitas pengelolaan masyarakat di suatu wilayah sangat ditentukan oleh kapasitas sumberdaya manusia (human capital) dan faktor modal sosial (social capital). Terdapat tiga unsur utama dari modal sosial, yaitu hubungan saling percaya, norma serta jejaring (network) dan keterkaitan (network)[7], sedangkan modal manusia menurut Mayo dalam Sukoco dan Prameswari (2017)[6] memiliki lima komponen utama, yaitu : individual capability, individual motivation, the organization climate, workgroup effectiveness dan leadership

Beberapa studi yang telah dilakukan menunjukkan bahwa modal sosial dan modal manusia mempunyai pengaruh yang positif terhadap keberhasilan pembangunan. Maulana (2009)[5] menyebutkan bahwa modal sosial dapat menciptakan kehidupan bermasyarakat yang aman dan dinamis untuk pembangunan menuju masyarakat yang adil dan makmur. Sementara itu Kusumastuti (2015) [4] menemukan bahwa kapasitas adaptasi yang dikembangkan oleh masyarakat melalui modal sosial terikat dapat mewujudkan daya lenting, fleksibilitas, dan stabilitas dalam pembangunan dan pengelolaan infrastruktur desa. Jaringan sosial yang semakin meningkat akan mempengaruhi tingkat partisipasi masyarakat dalam hal pembangunan infrastruktur di Desa Pajaran (Farisa dan Riska, 2018)[2]. Menurut penelitian Wirawan (2017)[9] modal manusia berpengaruh signifikan terhadap kinerja perusahaan pada PDAM di Kabupaten Tabalong.

Menurut berita dari beberapa media online menunjukkan bahwa di beberapa wilayah Pamsimas telah berhasil membantu masyarakat dalam penyediaan air minum. Berdasarkan data Sistem Informasi Manajemen (SIM) Keberlanjutan Pamsimas sampai dengan akhir tahun 2018 menunjukkan bahwa program telah dilaksanakan di 16.785 desa di seluruh Indonesia dan telah melayani sambungan rumah sebanyak 1260.135 dengan meteran air dan 612.257 tanpa meteran air. Capaian ini tidak lepas dari pengelolaan operasional dan pemeliharaan yang dilakukan masyarakat agar SPAM desa terus berfungsi optimal dalam menyediakan air minum.

Namun demikian dalam perkembangan pengelolaan SPAM Desa Pamsimas secara nasional menunjukkan adanya perbedaan dalam keberlanjutan SPAM dimana terdapat SPAM desa yang hanya berfungsi sebagian dan bahkan tidak berfungsi sebagaimana terlihat pada gambar.1. 


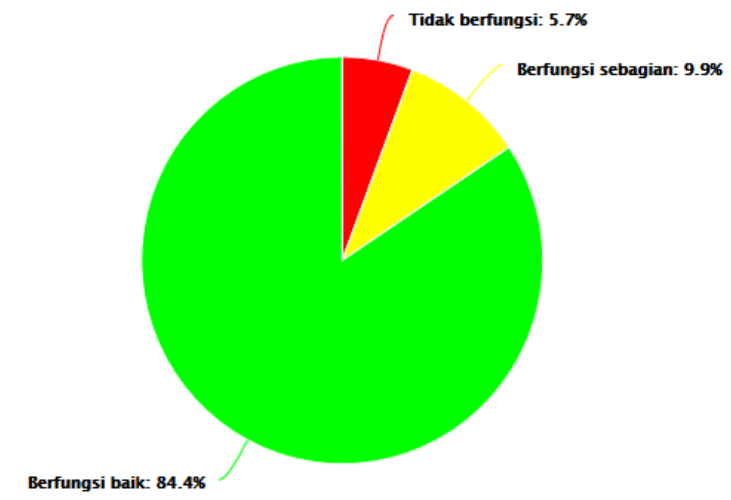

Gambar.2. Keberfungsian Sarana Air Minum Secara Nasional

Berdasarkan uraian tersebut diketahui adanya perbedaan yang terjadi dalam perkembangan SPAM yang sudah terbangun melalui program Pamsimas. Belum banyak penelitian tentang pengelolaan penyediaan air minum desa setelah beroperasi, oleh karena itu perlu kiranya untuk mengetahui bagaimana keberlanjutan penyediaan air minum berbasis masyarakat setelah beroperasi dan faktor-faktor apa saja yang mempengaruhi keberlanjutan tersebut.

\section{B. METODE PENELITIAN}

Pendekatan yang digunakan peneliti dalam penelitian ini adalah pendekatan kualitatif dengan metode studi kasus. Yin (2002) menyebutkan bahwa studi kasus merupakan strategi yang lebih cocok bila pokok pertanyaan suatu penelitian berkenaan dengan how (bagaimana) atau why (mengapa), bila peneliti hanya memiliki sedikit peluang untuk mengontrol peristiwaperistiwa yang akan diselidiki dan bilamana fokus penelitiannya terletak pada fenomena kontemporer (masa kini) di dalam konteks kehidupan nyata [10]. Peneliti menggunakan pendekatan ini karena pada penelitian ini melihat hasil dan keberlanjutan dari pembangunan yang sudah dilakukan pemerintah secara keseluruhan dan utuh yang berkaitan dengan sistem penyediaan air minum pedesaan. Selain itu penelitian ini juga membutuhkan data yang lebih detail sehingga deskripsi hasil penelitian lebih terperinci untuk melihat proses perkembangan SPAM Desa.

Desain penelitian yang dilakukan dalam penelitian ini adalah desain multi kasus holistik dengan dua kasus. Dua kasus yang digunakan dalam penelitian ini bertujuan untuk membandingkan antara persamaan dan perbedaan dari setiap kasus sehingga didapatkan penjelasan secara komprehensif mengenai bagaimana keberlanjutan penyediaan air minum berbasis masyarakat setelah terbangunnya infrastruktur SPAM pedesaan dan faktor-faktor apa saja yang menyebabkan adanya perbedaan keberlanjutan penyediaan air minum berbasis masyarakat.

Lokasi penelitian dilaksanakan di dua desa di Kabupaten Purworejo, yaitu: Desa Piji dan Desa Gintungan. Pemilihan ini didasarkan pada pertimbangan kedua desa tersebut telah selesai melaksanakan program penyediaan air minum berbasis masyarakat pada tahap pertama (Pamsimas I) dan infrastruktur SPAM di ke dua desa tersebut sudah beroperasi melakukan pelayanan air minum kepada warga. Sumber data didapat dengan cara wawancara yang mendalam terhadap para narasumber yang mengetahui fakta-fakta dan ikut berperan dalam kegiatan pengelolaan penyediaan air minum perdesaan yang terdiri dari perangkat desa, pengelola SPAM Desa, masyarakat pengguna dan fasilitator pendamping program Pamsimas. Selain itu juga dilakukan dengan observasi lapangan secara langsung untuk melihat kondisi SPAM dan mengkaji dokumen-dokumen terkait yang ada.

\section{HASIL DAN PEMBAHASAN}

\section{Keberlanjutan Penyediaan Air Minum Berbasis Masyarakat}

Setelah beroperasi mulai tahun 2012 setelah selesainya konstruksi SPAM melalui Program Pamsimas I, menunjukkan bahwa layanan air minum SPAM Desa Piji mengalami perkembangan yang signifikan. Sampai dengan akhir tahun 2018 layanan SPAM desa telah menjangkau seluruh wilayah desa dan sebagian besar warga sudah memanfaatkan layanannya. Jumlah sambungan rumah (SR) mengalami peningkatan dari tahun ke tahun dan kini telah berkembang menjadi 250 SR. Berdasar keterangan dari perangkat Desa Piji, mengatakan bahwa partisipasi masyarakat Desa Piji dalam pembangunan SPAM Desa sampai saat ini masih berjalan baik. Hal ini dilihat dari tingkat partisipasi yang tinggi pada setiap pembangunan SPAM Desa baik saat pelaksanaan Pamsimas I, bantuan HID dan Pamsimas III. Masih adanya budaya gotong royong dan sambatan /kerja bakti setiap ada kegiatan sosial menjadikan pembangunan SPAM di desa Piji berjalan dengan baik dan lancar serta berfungsi optimal sampai dengan saat ini. Dalam pemenuhan biaya operasional dan pemeliharaan, jumlah iuran dari para pelanggan sampai dengan saat ini masih berjalan lancar dan masih dapat menutup biaya pemeliharaan SPAM. Warga mau untuk membayar tarif iuran pemakaian air sebesar Rp.2.00o/m3 dan biaya beban operasional dan pemeliharaan sebesar Rp.6.0oo/bulan untuk wilayah datar dan Rp.8.0oo/bulan untuk wilayah yang tinggi. Tarif iuran yang sudah ditetapkan bersama dianggap tidak memberatkan para pelanggan. Kuantitas dan kualitas sumber air SPAM Desa Piji terus terjaga dan mampu memenuhi kebutuhan pengguna. Setiap enam bulan sekali pihak pengelola mengajukan uji kualitas air baik dari sumber maupun bak pengendapan untuk memenuhi standar dari Dinas Kesehatan. Pengelolaan SPAM Desa Piji pasca konstruksi dilakukan oleh Badan Pengelola SPAM (BP-SPAM) "TIRTO WENING". Kinerja pengelola dalam keberlanjutan SPAM Desa Piji sangat baik. dan mendapat apresiasi berupa Hibah Insentif Desa pada tahun 2014. Salah satu peningkatan layanan 
BP-SPAM "Tirta Wening" adalah memanfaatkan apikasi media sosial Grup Whatsapp untuk laporan permasalahan kerusakan jaringan air minum. Pengelola telah menerapkan aturan dan sanksi terkait hak dan kewajiban pengguna dan berlaku sampai saat ini. Keberlanjutan pengelolaan SPAM Desa mulai tahun 2017 di desa Piji diteruskan oleh KP-SPAM yang merupakan transformasi dari BP-SPAM dan menjadi bagian dari salah satu unit usaha BUMDES di Desa Piji.
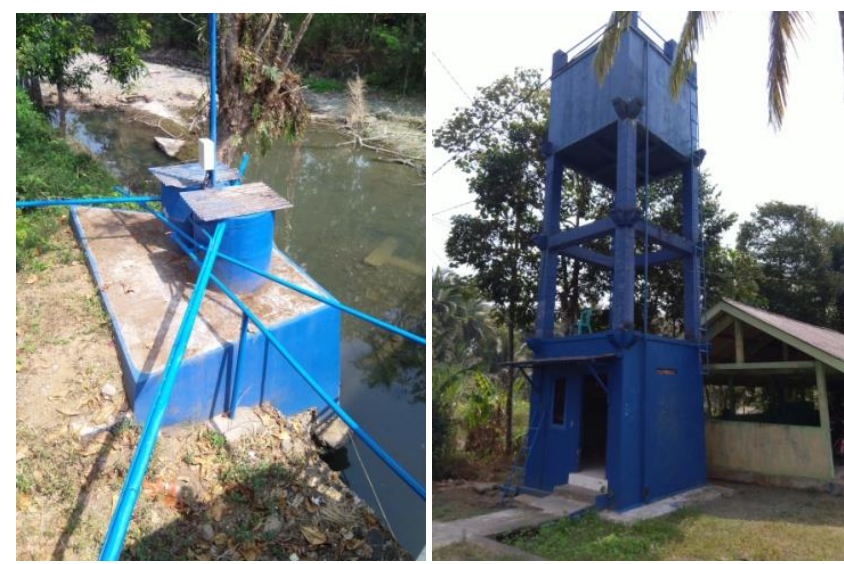

Gambar.3. Kondisi SPAM Desa Piji Tahun 2019

Sejak dioperasikan mulai tahun 2012, dari hasil wawancara dan observasi diketahui bahwa layanan SPAM Desa Gintungan terjadi penurunan. Pengguna layanan yang awalnya 90 SR turun menjadi 80 SR pada tahun 2016 dan berhenti operasi tahun 2017. Ketidakberfungsian SPAM Desa sejak tahun 2017 akibat kerusakan mesin pompa tidak pernah tertangani sampai saat ini. Partisipasi masyarakat Desa Gintungan yang tinggi saat pembangunan awal SPAM tidak terlihat dalam usaha menghidupkan kembali operasional SPAM, kontribusi incash masyarakat yang dulu dilakukan saat pembangunan tidak terjadi untuk perbaikan pompa yang rusak, pengelola hanya mengharapkan bantuan dari pemerintah desa. Kondisi keuangan SPAM desa dari iuran pelanggan tidak mampu lagi memenuhi biaya operasional dan pemeliharaan. Kemauan pengguna untuk membayar terus menurun walaupun iuran operasional; dan pemeliharaan hanya sebesar Rp1.ooo,/m3 dengan biaya beban Rp.1.ooo,-/bulan. Penurunan pengguna dan semakin banyak warga yang menggunakan keran umum yang ada untuk kebutuhan sehari-hari menambah berat beban yang harus ditanggung.

Secara kuantitas dan kualitas air dari sumber SPAM Desa Gintungan sudah bisa mencukupi kebutuhan dan memenuhi standar Dinas Kesehatan walaupun berubah dari rencana awal. Kondisi SPAM dan sumber air yang kurang terawat menunjukkan tidak adanya upaya perlindungan dan pemeliharaan terhadap sumber air.

Pengelolaan SPAM desa Gintungan di lakukan oleh BP-SPAM "Tirta Guna Sehat". Kelembagaan pengelola SPAM Gintungan saat penelitian keberadaannya masih ada tetapi tidak aktif. Sebenarnya pada awal operasional kinerja pengelola SPAM Desa Gintungan lumayan baik, tetapi seiring berjalannya waktu kinerjanya mulai menurun. Manajemen yang kurang baik ditambah lagi dengan tidak adanya norma aturan yang jelas dalam pemakaian air mempersulit dalam pengelolaan SPAM.

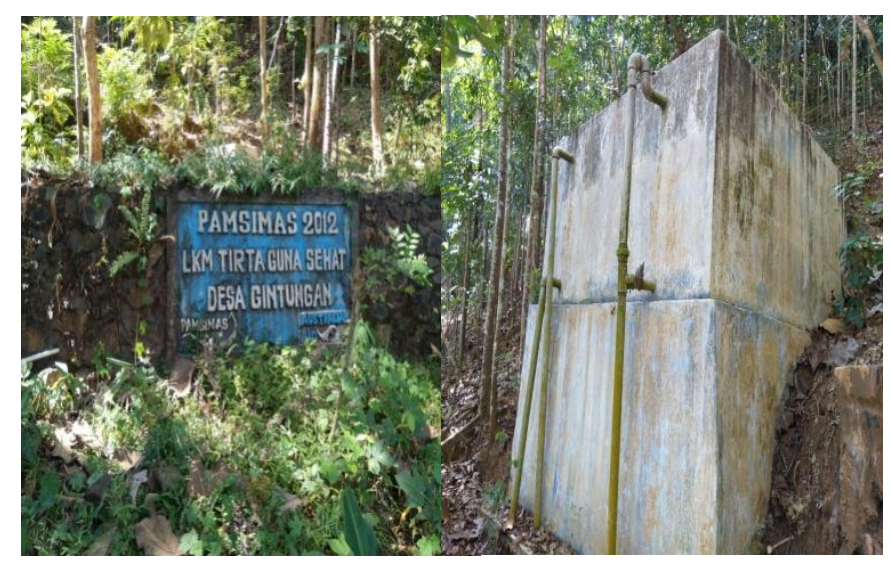

Gambar.4. Kondisi SPAM Desa Gintungan Tahun 2019

\section{Analisis Perbandingan Aspek-Aspek Keberlanjutan Penyediaan Air Minum}

Pada analisis aspek-aspek keberlanjutan penyediaan air minum dilakukan pengelompokan dari hasil uraian keberlanjutan penyediaan air minum pedesaan sebelumnya dengan tujuan untuk mendapatkan informasi yang komprehensif mengenai keberlanjutan penyediaan air minum pedesaan. Perbandingan keberlanjutan penyediaan air minum berbasis masyarakat pada lokasi penelitian ditampilkan pada tabel 1.

Tabel 1

Perbandingan Perkembangan Keberlanjutan Penyediaan Air Minum Berbasis Masyarakat Tiap Desa

\begin{tabular}{|c|c|c|}
\hline & Desa Piji & Desa Gintungan \\
\hline \multicolumn{3}{|l|}{ Aspek Sosial } \\
\hline $\begin{array}{l}\text { Akses Layanan Air } \\
\text { Minum }\end{array}$ & Berkembang & $\begin{array}{c}\text { Tidak } \\
\text { Berkembang }\end{array}$ \\
\hline $\begin{array}{l}\text { Partisipasi } \\
\text { Masyarakat }\end{array}$ & $\begin{array}{c}\text { Kontribusi } \\
\text { dalam } \\
\text { pembangunan } \\
\text { tinggi }\end{array}$ & $\begin{array}{c}\text { Kontribusi } \\
\text { dalam } \\
\text { pembangunan } \\
\text { turun }\end{array}$ \\
\hline \multicolumn{3}{|l|}{ Aspek Ekonomi } \\
\hline $\begin{array}{c}\text { Biaya Operasional } \\
\text { dan Pemeliharaan } \\
\text { Kemauan } \\
\text { Membayar Iuran }\end{array}$ & $\begin{array}{l}\text { BOP }<\text { Jumlah } \\
\text { Iuran }\end{array}$ & $\begin{array}{c}\text { BOP }>\text { Jumlah } \\
\text { Iuran } \\
\text { Awal tinggi } \\
\text { kemudian } \\
\text { menurun } \\
\end{array}$ \\
\hline \multicolumn{3}{|l|}{ Aspek lingkungan } \\
\hline Kuantitas Air & Mencukupi & Mencukupi \\
\hline $\begin{array}{l}\text { Kualitas Air } \\
\text { Upaya }\end{array}$ & Baik & Baik \\
\hline $\begin{array}{l}\text { Perlindungan } \\
\text { Sumber Air }\end{array}$ & Ada & Tidak Ada \\
\hline \multicolumn{3}{|l|}{$\begin{array}{c}\text { Aspek } \\
\text { Kelembagaan }\end{array}$} \\
\hline Lembaga Pengelola & Ada dan aktif & Hanya sebagian \\
\hline
\end{tabular}




\begin{tabular}{ccc}
\hline & Desa Piji & Desa Gintungan \\
\hline & & yang aktif \\
Aturan dan Norma & $\begin{array}{c}\text { Ada aturan dan ada } \\
\text { sanksi yang jelas }\end{array}$ & $\begin{array}{c}\text { aturan dan } \\
\text { sanksi yang jelas }\end{array}$ \\
\hline
\end{tabular}

Sumber:Analisis, 2019

Dari tabel 1 dapat diketahui bahwa terdapat perbedaan perkembangan keberlanjutan SPAM Pedesaan pasca konstruksi. Penyediaan Air Minum Desa Piji mengalami keberlanjutan sedangkan Desa Gintungan tidak mengalami keberlanjutan.

Berdasarkan tabel 1 memperlihatkan bahwa dari aspek sosial, pelayanan sistem penyediaan air minum pada Desa Piji mengalami peningkatan dan perkembangan yang cukup signifikan. Perkembangan ini mencakup luas wilayah pelayanan, jumlah pengguna dan panjang jaringan. Selain itu partisipasi masyarakat dalam penyediaan air minum terus terjaga yang terbukti dari masih tingginya kontribusi warga dalam program penyediaan air minum melalui sumbangan baik berupa uang, tenaga maupun material. Kondisi berbeda terjadi pada sistem penyediaan air minum berbasis masyarakat di Desa Gintungan. Pelayanan sistem penyediaan air minum desa berbasis masyarakat yang ada terus mengalami penurunan bahkan sudah tidak dapat beroperasi lagi. Upaya perbaikan dan pengoperasian kembali sistem penyediaan air minum desa yang ada menghadapi kendala dalam biaya perbaikan. Partisipasi warga desa tidak sama seperti pada saat pembangunan dulu dikarenakan banyak warga yang sudah membangun dan memiliki sumber air sendiri.

Dari aspek ekonomi/keuangan sistem penyediaan air minum pada Desa Piji, jumlah dana iuran yang terkumpul setiap bulannya mampu memenuhi kebutuhan biaya operasional dan pemeliharaan sistem penyediaan air minum kedua desa tersebut, selain itu sisa dana iuran yang terkumpul dipakai sebagai dana cadangan apabila terjadi kerusakan peralatan penyediaan air minum. Tercukupinya kebutuhan biaya operasional sistem tidak terlepas dari tingginya tingkat kemauan iuran dari semua warga pengguna yang merasa puas dengan pelayanan yang diberikan dalam penyediaan air minum. Hal ini berbeda dengan kondisi di Desa Gintungan. Kondisi di Desa Gintungan menunjukkan bahwa terjadi penurunan jumlah pelanggan yang mengakibatkan penurunan jumlah dana iuran yang terkumpul. Penurunan yang terjadi semakin lama berimplikasi kepada biaya operasional dan pemeliharaan SPAM Desa hingga pada tahun 2017 sudah tidak mampu lagi untuk memperbaiki kerusakan alat yang ada sehingga pelayanan terhenti.

Dari aspek lingkungan, kuantitas dan kualitas air dalam penyediaan air minum di Desa Piji terjaga dengan baik. Kuantitas air dari sumber penyediaan air minum sangat mencukupi untuk memenuhi kebutuhan para pengguna dan memperluas jaringan layanan. Secara kualitas, air minum dari layanan kedua SPAM desa ini sudah memenuhi standar dari Dinas Kesehatan. Adanya upaya untuk menjaga kelestarian sumber air mendukung keberlanjutan sistem dalam penyediaan air minum pedesaan di kedua desa. Sedangkan pada Desa Gintungan menunjukkan bahwa kuantitas sumber air yang digunakan dalam sistem penyediaan air minum sebenarnya cukup untuk memenuhi kebutuhan para pengguna. Demikian juga dengan kualitas air yang dimiliki oleh sumber dan sistem penyediaan juga telah memenuhi kualitas yang disyaratkan oleh Dinas Kesehatan. Upaya perlindungan terhadap sumber air di kedua desa belum ada.

Dari aspek kelembagaan dalam penyediaan air minum terdapat perbedaan dalam keberlanjutan pengelolaan SPAM Desa. Pada Desa Piji menunjukkan bawa lembaga pengelola sistem penyediaan air minum yang terbentuk (BPSPAM) memiliki kinerja yang baik. Hal ini diperkuat dengan adanya aturan dan sanksi yang jelas dalam pengelolaan sistem penyediaan air minum membuat mudah dalam pengelolaan walaupun penerapannya belum optimal. Kondisi berbeda terjadi pada kelembagaan pengelola SPAM di Desa Gintungan. Pada kedua desa ini kelembagaan pengelola yang terbentuk tidak berfungsi sebagaimana mestinya, dalam pengelolaan operasional dan pemeliharaan SPAM desa hanya sebagian pengurus saja yang aktif dan pada akhirnya vakum karena SPAM sudah tidak berfungsi lagi. Belum adanya aturan yang jelas mengatur pengelolaan SPAM desa membuat pengelola kesulitan dalam menjalankan sistem penyediaan air minum desa.

\section{Modal Sosial dalam Keberlanjutan Penyediaan Air Minum}

Empat desa penelitian mempunyai tipe modal sosial yang sama yaitu bonding social capital dalam penyediaan air minum bagi desa. Ikatan yang terjalin antar warga di keempat desa tersebut didasari keinginan bersama untuk memenuhi kebutuhan air minum yang layak dan berkelanjutan. Hubungan sosial ini menumbuhkan partisipasi yang tinggi pada saat pembangunan SPAM Desa. Setelah beroperasinya SPAM Desa beberapa tahun kemudian, partisipasi warga dalam keberlanjutan penyediaan air minum di Desa Piji dan masih tinggi dan berjalan. Masih tingginya tingkat partisipasi warga di Desa Piji disebabkan terpeliharanya kepercayaan warga terhadap penyediaan air minum oleh BP-SPAM Desa. Kondisi berbeda dialami Desa Gintungan, semakin berkurangnya kepercayaan warga terhadap pelayanan SPAM desa menyebabkan penurunan partisipasi warga dalam keberlanjutan penyediaan air minum desa. Penerapan norma yang mengatur penyediaan air minum desa juga terdapat perbedaan dimana tiga desa mempunyai norma aturan yang disepakati bersama sedangkan pada desa yang lain tidak terdapat norma aturan. 


\section{Modal Manusia dalam Keberlanjutan Penyediaan Air Minum}

Dua desa penelitian mempunyai potensi modal manusia yang cukup besar. Kompetensi yang dimiliki penduduk ke dua desa memperlihatkan tingkatan yang hampir sama ditinjau dari tingkat pendidikan penduduk, rata-rata pendapatan. Demikian juga dengan motivasi awal para pelanggan air minum di keempat desa tersebut yang sama-sama ingin mendapatkan air minum yang bagus, mudah dan murah untuk memenuhi kebutuhan sehari-hari. Motivasi masyarakat ini semakin tinggi pada Desa Piji setelah melihat pelayanan yang dilakukan oleh pengelola sistem penyediaan air minum desa. Komitmen yang tinggi dari pengelola SPAM di Desa Piji dalam melakukan pelayanan penyediaan air minum telah berhasil memuaskan pelanggan. Efektivitas tim pengelola dalam penyediaan air di Desa Piji dengan adanya pembagian kerja yang jelas berhasil meningkatkan kinerja pengelolaan dan pelayanan SPAM. Adanya dukungan dari kepala desa dan aktor penggerak pengelolaan menjadikan keberlanjutan SPAM desa Piji sampai saat ini. Kondisi berbeda terjadi pada Desa Gintungan, kurangnya komitmen dan tidak efektifnya kinerja dari pengelola di kedua desa menyebabkan penyediaan layanan air minum terus menurun dan berhenti. Hal ini ditambah lagi dengan tidak adanya dukungan dari pemangku wilayah dan aktor penggerak pengelolaan SPAM menjadikan permasalahan tidak menemukan solusi. Motivasi masyarakat Desa Gintungan menurun setelah masyarakat sudah mampu menyediakan air mandiri karena SPAM tidak berfungsi.

\section{Analisis Pengaruh Faktor Modal Sosial dan Modal Manusia}

Dari hasil pembahasan peran modal sosial dan modal manusia yang telah dijelaskan sebelumnya dapat diketahui bahwa modal sosial dan modal manusia merupakan faktor yang sangat mempengaruhi dalam keberlanjutan penyediaan air minum berbasis masyarakat. Untuk memahami faktor modal sosial dan modal manusia yang mempengaruhi keberlanjutan penyediaan air minum seperti yang dijelaskan pada pembahasan sebelumnya dapat dilihat pada tabel 2.

Tabel 2.

Analisis Faktor Keberlanjutan Penyediaan Air Minum

\begin{tabular}{lll}
\hline Faktor Pengaruh & Desa PIji & $\begin{array}{c}\text { Desa } \\
\text { Gintungan }\end{array}$ \\
\hline Modal Sosial & & \\
\hline Jaringan & Kuat & Lemah \\
Trust & Tinggi & Rendah \\
Norma & Ada & Ada \\
\hline
\end{tabular}

Modal Manusia

\begin{tabular}{lll}
\hline Kompetensi & $\begin{array}{l}\text { Cukup } \\
\text { Tinggi }\end{array}$ & $\begin{array}{l}\text { Cukup } \\
\text { Tinggi }\end{array}$ \\
Motivasi & Tinggi & Rendah \\
Komitmen & Tinggi & Rendah \\
Efektivitas Tim & Efektif & Tidak \\
Kepemimpinan & Baik & Kurang \\
\hline
\end{tabular}

Sumber:Analisis, 2019

Dari tabel 2. dapat diketahui bahwa Desa Piji dan mempunyai modal sosial yang kuat. Hubungan sosial masyarakat dan jaringan yang terbentuk dalam masyarakat yang cenderung kuat memudahkan pengelola dalam meningkatkan partisipasi masyarakat dalam penyediaan air minum. Kepercayaan masyarakat yang tinggi terhadap pengelolaan SPAM Desa memudahkan pengelola dalam meningkatkan kemauan pelanggan untuk membayar iuran operasional dan pemeliharaan SPAM. Adanya aturan yang mengikat dan diterapkan dengan baik di Desa Piji menambah kuat kepercayaan dan hubungan sosial yang terbentuk dalam penyediaan air minum walaupun penerapan aturan yang ada belum optimal. Modal manusia Desa Piji berdasarkan tabel 2 juga menunjukkan tingkatan cukup kuat. Kapabilitas masyarakat yang sedikit berbeda ternyata tidak memberikan pengaruh yang signifikan dalam keberlanjutan penyediaan air minum di kedua desa. Motivasi masyarakat desa yang tinggi dalam memenuhi kebutuhan air minum mempercepat dalam pengembangan layanan jaringan SPAM. Komitmen yang tinggi dalam melakukan layanan dan kerja tim yang efektif dalam pengelolaan menjadikan SPAM desa dapat terus beroperasi dan memberikan kepuasan kepada masyarakat pelanggan selain itu kepemimpinan yang mendukung dan aktif dalam merespon kebutuhan masyarakat menjadikan penyediaan air minum dan lembaga pengelola dapat berjalan dan berkinerja baik.

Dalam tabel 2 diketahui bahwa modal sosial Desa Desa Gintungan memiliki kondisi yang berbeda dengan Desa Piji. Hubungan sosial dan jaringan yang terbentuk di kedua desa dalam penyediaan air minum yang cenderung lemah menyebabkan menurunnya partisipasi masyarakat desa. Rendahnya kepercayaan masyarakat kepada pengelola menjadikan berkurangnya sumber biaya operasional dan pemeliharaan dari iuran, kemauan warga untuk membayar juga semakin menurun. Tidak adanya norma aturan yang jelas membuat lembaga pengelola tidak bisa memberikan sanksi bagi masyarakat yang melanggar, norma yang ada selama ini berupa nilai-nilai kearifan lokal. Modal manusia berupa kapabilitas pengelola dan masyarakat di Desa Gintungan termasuk cukup baik untuk mendukung keberlanjutan sistem penyediaan air minum desa, akan tetapi rendahnya motivasi masyarakat dalam keikutsertaan penyediaan air minum dan rendahnya komitmen pengelola dalam pengembangan dan 
pelayanan menyebabkan layanan tidak berkembang bahkan menurun. Tidak adanya kepemimpinan yang mampu menggerakkan dan mencari solusi yang baik di kedua desa mengakibatkan kelembagaan pengelola tidak berjalan dan vakum.

Keberlanjutan pengembangan layanan air minum menuntut adanya modal sosial dan modal manusia yang kuat untuk menggerakkan sistem penyediaan air minum berbasis masyarakat. Dari hasil analisis terhadap indikator-indikator setiap variabel modal sosial dan modal manusia dapat disimpulkan bahwa modal sosial dan modal manusia yang dimiliki oleh Desa Piji dan lebih besar dibanding Desa Gintungan. Adanya jaringan yang kuat, kepercayaan masyarakat yang tinggi, dan juga norma aturan yang berlaku menggambarkan bahwa modal sosial yang terdapat di Desa Piji termasuk besar dan memiliki pengaruh yang kuat dalam keberlanjutan penyediaan air minum. Demikian juga halnya dengan modal manusia yang berupa motivasi masyarakat yang tinggi, komitmen pengelola yang tinggi, efektivitas kerja yang baik dan adanya pengelola serta pemangku wilayah yang memiliki leadership yang baik menunjukkan bahwa modal manusia Desa Piji besar dan juga berpengaruh dalam keberlanjutan penyediaan air minum desa.

\section{SIMPULAN DAN SARAN}

Penyediaan air minum pedesaan dengan pendekatan berbasis masyarakat mempunyai keberlanjutan yang berbeda-beda. Desa dengan keberlanjutan pada aspek sosial, keuangan, lingkungan dan kelembagaan mempunyai tingkat keberlanjutan yang sangat baik sedangkan desa dengan keberlanjutan hanya pada salah satu aspek saja mempunyai tingkat keberlanjutan yang rendah.

Keberlanjutan SPAM Desa sangat dipengaruhi oleh modal sosial dan modal manusia yang dimiliki. Faktor modal sosial yang mempengaruhi berupa jaringan hubungan sosial yang kuat, kepercayaan yang tinggi, dan adanya norma aturan, sedangkan faktor modal manusia yang berpengaruh berupa motivasi, komitmen, efektivitas tim kerja dan kepemimpinan.

Mengingat pentingnya peran modal sosial dan modal sosial maka peningkatan dan penguatan kedua modal tersebut menjadi sebuah tantangan dalam keberlanjutan penyediaan air minum untuk mencapai target universal acces air minum. Penguatan dan pemberdayaan masyarakat desa oleh Pemerintah Daerah harus ditingkatkan dan dipandang sebagai bentuk investasi dalam mewujudkan keberhasilan pembangunan pedesaan.

\section{DAFTAR RUJUKAN}

[1] Badan Perencanaan Pembangunan Nasional, Kebijakan Nasional Pembangunan Air Minum dan Penyehatan Lingkungan Berbasis Masyarakat, Jakarta : Badan Perencanaan Pembangunan Nasional, 2003.
[2] Farisa, B.M.R. (2018). Keterkaitan Modal Sosial Dengan Partisipasi Masyarakat Dalam Pembangunan Infrastruktur (Program Alokasi Dana Desa) Desa Pajaran Kecamatan Poncokusumo, Sarjana Thesis, Universitas Brawijaya, 2018.

[3] Kamulyan, P. Wiguna, I.P.A. dan Slamet, A, Penilaian Keberlanjutan Pengelolaan Sistem Penyediaan Air Minum Berbasis Masyarakat Di Kota Blitar. Insitut Teknologi Sepuluh November Journal Of Civil Engineering, 32(2). 60-68, 2017.

[4] Kusumastuti, A, Modal Sosial dan Mekanisme Adaptasi Masyarakat Pedesaan dalam Pengelolaan dan Pembangunan Insfrastruktur, MASYARAKAT : Jurnal Sosiologi,20(1), 81-97, 2015.

[5] Maulana, F, Pemanfaatan Modal Sosial Masyarakat Pada Program Pembangunan Gampong (PPG) Kecamatan Baktiya Barat Kabupaten Aceh Utara, Tesis, Universitas Sumatera Utara, 2009.

[6] Sukoco, I. dan Prameswari, D, Human Capital Approach To Increasing Productivity Of Human Resources Management., Jurnal AdBispreneur.,2((1), 93-104, 2017

[7] Rustiadi, E., Saefulhakim, S., \& Panuju, R. D, Perencanaan dan Pengembangan Wilayah, Jakarta, Indonesia: Yayasan Obor Indonesia, 2009.

[8] Trijunianto, O, Analisis Faktor Keberlanjutan Sarana Air Minum Program Pamsimas Di Kabupaten Kupang Provinsi Nusa Tenggara Timur, Tesis. Institut Teknologi Sepuluh Nopember, 2016.

[9] Wirawan, S, Pengaruh Human Capital, Structural Capital, Dan Customer Capital Terhadap Kinerja Perusahaan Pada Perusahaan Daerah Air Minum (PDAM) Di Kabupaten Tabalong. Jurnal Administrasi Publik dan Administrasi Bisnis. Vol.1 No.2, 387-404, 2017.

[10] Yin, R. K, Studi Kasus Desain dan Metode, Jakarta : PT Raja Grafindo Persada , 2002. 